\title{
The Effects of Potato Puree and Bread Crumbs on Some Quality Characteristics of Low Fat Meatballs
}

\author{
Haluk Ergezer,*, Tolga Akcan ${ }^{1}$, and Meltem Serdaroğ lu ${ }^{2}$ \\ ${ }^{1}$ Pamukkale University, Faculty of Engineering, Department of Food Engineering, Denizli, Turkey \\ ${ }^{2}$ Ege University, Faculty of Engineering, Department of Food Engineering, Izmir, Turkey
}

\begin{abstract}
The purpose of this study was to determine the effects of using different amounts of potato puree (PP) (10 or 20\%) and $10 \%$ bread crumbs (BC) as an extender and also control samples (C) with no added extender on chemical composition, energy values, cooking analyses, colour measurements, water holding capacity (WHC), penetration values, thiobarbituric acid value (TBA) and sensory analyses of meatballs. Meatball samples were cooked in a pre-heated $180^{\circ} \mathrm{C}$ electric oven. Uncooked meatballs formulated with $20 \%$ PP had the highest moisture content. No significant differences were recorded for protein contents of uncooked samples. The highest cooking yield was found in samples extended with $10 \% \mathrm{BC}$. Increasing PP from $10 \%$ to $20 \%$ increased cooking yield of meatballs. $20 \%$ PP increased moisture and fat retention values and water holding capacity of meatballs. Meatballs with $10 \% \mathrm{BC}$ had the lowest (the hardness in the texture) and meatballs with the $20 \%$ PP had the highest (the softness in the texture) penetration values. Formulating meatballs at a level of $20 \%$ resulted lower L* values. TBA values of control samples were higher than in PP added samples at the end of the storage period. Flavour scores for meatballs formulated with PP were higher than control and meatballs formulated with BC. Meatballs formulated with $10 \%$ PP had similar overall acceptability with meatballs added with $10 \%$ BC.
\end{abstract}

Keywords: beef meat, meatball, potato, oxidation, low fat products

\section{Introduction}

Meat products in ground form such as burgers, patties and meatballs are very popular in Turkey. Moistened or dried bread crumbs are usually used as binders and extenders in this type of meat products. However to produce healthier meat products researches concentrated on adding various plant sourced extenders and binders such as soy bean (Gujral et al., 2002) tomato paste (Candogan, 2002), lentil, black eye bean and chickpea flour (Serdaroglu et al., 2005), corn flour (Serdaroglu and Degirmencioglu, 2004), oat flour (Serdaroglu, 2006) carrot and potato (Devatkal et al., 2004), walnuts (Colmenero et al., 2005) hazelnut pellicle (Turhan et al., 2005) dried apricot pulp (Purma and Serdaroglu, 2008) and broccoli puree (Ergezer and Serdaroglu, 2009).

Vegetables occupy an important role in human nutrition as they provide essential minerals, vitamins and are also

*Corresponding author: Haluk Ergezer, Pamukkale University, Faculty of Engineering, Department of Food Engineering, Denizli, Turkey, Tel: +90-258-396-33-39, E-mail: hergezer@pau. edu.tr known to contain large amount of dietary fiber and phytochemicals that are natural antioxidants (Xu, 2001). Vegetables could also serve as fillers, binders, fat replacers and sources of dietary fiber and natural antioxidants in a meat system (Hedrick et al., 1994).

Extension of meat and meat products with vegetables could reduce production costs and improve the nutritional qualities of the products. However, the relevance of fruits and vegetables in processing of meat products relates to their functional properties such as water and fat binding, fat emulsification, yield and sensory properties. Incorporation of tomato puree at $15 \%$ resulted lower cooking loss and increase moisture retention and had no effect on sensory scores of beef patties (Candogan, 2002). Fresh plum juice concentrate, dried plum and spray dried plum powder at 2.5 or $5 \%$ increased the percentage cook loss and did not affect the purge loss of hams (Nunez de Gonzalez et al., 2008). The addition of $12 \%$ tomato paste had no effect on purge accumulation of frankfurters (Deda et al., 2007). Incorporation of meatballs with $5 \%$ plum puree increased moisture retention (Y1ldiz-Turp and Serdaroglu, 2010).

Good color development, high scores for appearance and 
odor have been reported by Fista et al. (2004) for Greek traditional sausages formulated with 24\% leek. Addition of $2 \%$ carrot and $10 \%$ spinach improved the oxidative stability of poultry hamburgers (Pizzocaro et al., 1998). The sensory quality of the hamburgers remains good up to dried tomato peel concentrations of $4.5 \%$ (Garcìa et al., 2009).

Numerous studies have focused on functional properties of potato flour, potato protein and potato fiber in meat products. Puolanne and Ruusunen (1983) showed that the water-binding of potato flour in emulsion type sausages is dependent of its content in the formulation. Ikhlas et al. (2011) found that the addition of potato flour increased the cooking yield of meatballs. Nieto et al. (2009) have found that potato proteins at a level of $2 \%$ significantly reduced cooking losses and had a significant effect on lipid oxidation in emulsion type of sausages. The addition of potato pulp fiber enhanced the texture of low fat sausages (El-Anany and Ali, 2007). El-Anany and Ali (2007) indicated that mixtures of potato peel powder and rusk at ratios 1:1 can be successfully used as coating agents for fried chicken.

In this study potato puree prepared with skinned on was selected as potential extender for meatballs. The objective of this study was to investigate the effects of potato puree on proximate composition, cooking properties and some quality parameters of meatballs and compared with the meatballs extended with bread crumbs.

\section{Material and Methods}

\section{Sample Preparation}

Beef as boneless rounds was obtained from a local market. All subcutaneous fat and intramuscular fat was removed from the muscles and used as the fat source. Lean and fat were ground in a $3.5 \mathrm{~mm}$ plate grinder. Potatoes (Solanum tuberosum, $82.6 \%$ moisture, $1.33 \%$ protein, $0.15 \%$ fat, $15.54 \%$ carbohydrates, $0.38 \%$ ash) and toasted bread crumbs $(27.2 \%$ moisture, $12.4 \%$ protein, $2 \%$ fat, $56.4 \%$ carbohydrates, $2 \%$ ash) were purchased from a local market. Potatoes were washed and cooked for 45 min in boiling water than mashed (skin on) by using kitchen type food processor to obtain potato puree. Toasted bread crumbs were rehydrated with water before used for obtain equal moisture conditions to potato puree $3: 1(\mathrm{v} /$ $\mathrm{w})$.

In this research meatball samples produced with $10 \%$ potato puree (10PP), $20 \%$ potato puree (20PP) and $10 \%$ bread crumbs (10BC) were formulated (Table 1). Control samples with no added extender were also prepared (C). The minced beef ( $3 \%$ fat content) was mixed with extender (potato puree or bread cumbs), $7 \%$ beef fat, $1.5 \%$ salt, $0.3 \%$ black pepper and $0.5 \%$ red pepper. Batches of $2 \mathrm{~kg}$ of each formulation were mixed with a food processor and processed into meatballs $(1 \mathrm{~cm}$ thick and $80 \mathrm{~mm}$ diameter) by using a metal shaper. Meatballs were stored in polythene bags at $2^{\circ} \mathrm{C}$ for $6 \mathrm{~d}$.

Two replications of the experiment were conducted each at separate times. For each replication five meatballs were examined for proximate composition, cooking properties, colour, water holding capacity (WHC), penetration value and TBA value and sensory properties.

\section{Chemical composition}

Moisture, protein and ash content of uncooked and cooked meatball samples were measured by using AOAC (2007) procedures. Fat content was determined by chloroform-methanol extraction according to Flynn and Bramblett (1975). All the chemical composition analyses were calculated on wet basis.

\section{Energy values}

Total calories (kcal) were calculated in relation to samples of $100 \mathrm{~g}$ using the Atwater values corresponding to fat $(9 \mathrm{kcal} / \mathrm{g})$, protein $(4.02 \mathrm{kcal} / \mathrm{g})$ and carbohydrates (3.87 kcal/g) according to Mansour et al. (1999).

\section{Cooking method and cooking analyses}

Meatballs were cooked in a pre-heated $180^{\circ} \mathrm{C}$ electric oven which were standardised for temperature using a surface thermocouple (to give an internal temperature of $72^{\circ} \mathrm{C}$ ) approximately 35 mins. Percent cooking yield was

Table 1. Formulation of meatball samples

\begin{tabular}{ccccccc}
\hline \hline Samples & Meat $(\mathrm{g})$ & Spice Mix $(\mathrm{g})$ & Salt $(\mathrm{g})$ & Fat $(\mathrm{g})$ & Extender $(\mathrm{g})$ & Total $(\mathrm{g})$ \\
\hline C & 1814 & 16 & 30 & 140 & 0 & 2000 \\
10BC & 1614 & 16 & 30 & 140 & 200 & 2000 \\
10PP & 1614 & 16 & 30 & 140 & 200 & 2000 \\
20PP & 1414 & 16 & 30 & 140 & 400 & 2000
\end{tabular}

C: Control, 10BC: 10\% Bread crumbs, 10PP: 10\% Potato puree, 20PP: 20\% Potato puree 
determined by calculating weight differences for samples before and after cooking. Five meatballs for each replication were examined for cooking yield and fat retention according to Murphy et al. (1975).

$$
\text { Cooking Yield }(\%)=\frac{(\text { Cooked meatball weight })}{(\text { Uncooked meatball weight })} \times 100
$$

Fat retention $(\%)=$

$\left[\frac{(\text { Cooked weight }) \times(\% \text { Fat in cooked meatball })}{(\text { Raw weight }) \times(\% \text { Fat in raw meatball })}\right] \times 100$

The moisture retention value represents the amount of moisture retained in the cooked product per $100 \mathrm{~g}$ of sample and was determined according to an equation described by El-Magoli et al. (1996).

Moisture retantion (\%)

$=\underline{(\% \text { yield } \times \% \text { moisture in cooked meatball })}$

$$
100
$$

\section{Color measurement}

Color was measured at the surface of uncooked meatballs during the storage at $2^{\circ} \mathrm{C}$ for $6 \mathrm{~d}$. Five measurements were taken from each formulation on $0,2,4$. and 6 d. Color Flex A60-1010-615 Manual Version 23 Hunter Lab spectrocolorimeter equipped with the light source illuminant D65 (100 standard observer) was used for measurement. Colour coordinate values $\left(\mathrm{L}^{*}, \mathrm{a}^{*}, \mathrm{~b}^{*}\right)$ were recorded. Before each measurement the apparatus was standardized against a white plate.

\section{Water holding capacity measurement}

A filter press technique was used to determine water holding capacity (WHC) of cooked meatballs (Zayas and Lin, 1998). Lower values indicate better water holding capacity.

\section{Penetretion value}

A Sommer Runge-Model, KG PNR-6 penetrometer equipped with a total $100 \mathrm{~g}$ load weight was used to evaluate cooked meatballs (ve meatballs were used for each replication) for hardness. Depth of puncture was determined to $1 / 10 \mathrm{~mm}$ in triplicate for each meatball sample. The lower depth indicates harder texture (Candogan and Kolsarici, 2003).

\section{Thiobarbituric acid value}

Uncooked meatball samples were stored at $2^{\circ} \mathrm{C}$ for $6 \mathrm{~d}$ in polypropylene boxes with lids. At $0^{\text {th }}$ (after processing), $2^{\text {nd }}, 4^{\text {th }}$ and $6^{\text {th }} \mathrm{d}$ of storage, the oxidative rancidity was determined by using the TBA distillation procedure of Tarladgis et al. (1960). Each sample was analyzed in duplicate and results were expressed as $\mathrm{mg}$ of malonaldehyde (MDA) per $\mathrm{kg}$ of meat.

\section{Sensory analyses}

Samples from each formulation were randomly assigned for sensory evaluation. Meatballs were served warm to a ten-member trained panel. An eight point scale was used where $8=$ extremely desirable, extremely juicy, intense in beef flavor, extremely tender, acceptable and 1 = denoted extremely undesirable, extremely dry, devoid of beef flavor, tough and unacceptable. Water and bread were served for cleaning the mouth between samples.

\section{Statistical Analyses}

One-way ANOVA (SPSS, 2003) was applied for chemical composition, cooking measurements, WHC, color and sensory analyses. In the case of TBA and colour analyses two-way ANOVA was applied (SPSS, 2003). Significant means were separated using the least significant difference $(p<0.05)$ test $(\mathrm{LSD})$.

\section{Results}

Chemical composition and energy values of meatball samples are given in Table 2. Uncooked meatball samples had a moisture content ranging from 61.7 to $67.6 \%$. The moisture content was lower in samples extended with bread crumbs than other treatment groups. On the other hand the uncooked meatballs formulated with 20\% PP had the highest $(p<0.05)$ moisture content. No significant differences $(p>0.05)$ were recorded for protein content of uncooked samples (protein content changed from 17.0 to $18.1 \%$ ). No significant differences were found in ash content that changed from 2.2 to $2.3 \%$.

For cooked meatballs moisture content ranged from 53.3 to $57.6 \%$, fat content ranged from 11.8 to $15.6 \%$ and protein content ranged from 21.0 to $23.2 \%$. Control samples had the highest fat content $(15.6 \%)$ and PP20 samples had the highest moisture $(57.6 \%)$ content. No significant differences $(p<0.05)$ were recorded for protein contents of cooked samples (protein content changed from 21.0 to $23.2 \%$ ). The lowest energy values were found in 20PP samples both uncooked (167.9 kcal/100g) and cooked $(217.9 \mathrm{kcal} / 100 \mathrm{~g})$ meatballs.

Cooking characteristics of meatballs are given in Table 3. Cooking yield varied between 59.7 to $77.2 \%$. The highest cooking yield was found in samples extended with 
Table 2. Chemical composition and energy values of meatballs

\begin{tabular}{cccccc}
\hline \hline Sample uncooked & Moisture (\%) & Fat (\%) & Protein (\%) & Ash (\%) & Energy (kcal/100g) \\
\hline C & $66.0^{\mathrm{ab}} \pm 3.57$ & $13.0^{\mathrm{a}} \pm 2.29$ & $18.1 \pm 2.13$ & $2.3^{\mathrm{a}} \pm 0.01$ & $191.26^{\mathrm{a}} \pm 0.92$ \\
$10 \mathrm{BC}$ & $61.7^{\mathrm{b}} \pm 3.92$ & $11.4^{\mathrm{a}} \pm 3.75$ & $18.0 \pm 1.85$ & $2.3^{\mathrm{a}} \pm 0.08$ & $200.44^{\mathrm{a}} \pm 0.66$ \\
$10 \mathrm{PP}$ & $66.8^{\mathrm{a}} \pm 2.08$ & $10.5^{\mathrm{a}} \pm 2.68$ & $17.7 \pm 0.58$ & $2.3^{\mathrm{a}} \pm 0.01$ & $176.08^{\mathrm{b}} \pm 1.08$ \\
$20 \mathrm{PP}$ & $67.6^{\mathrm{a}} \pm 2.41$ & $9.5^{\mathrm{b}} \pm 2.35$ & $17.0 \pm 0.68$ & $2.2^{\mathrm{b}} \pm 0.11$ & $167.94^{\mathrm{b}} \pm 0.56$ \\
\hline Sample cooked & Moisture (\%) & Fat (\%) & Protein (\%) & Ash (\%) & Energy (kcal/100g) \\
\hline C & $57.2^{\mathrm{a}} \pm 2.82$ & $15.6^{\mathrm{a}} \pm 1.03$ & $23.2 \pm 0.92$ & $2.8^{\mathrm{a}} \pm 0.04$ & $232.88^{\mathrm{a}} \pm 1.14$ \\
$10 \mathrm{BC}$ & $53.30^{\mathrm{b}} \pm 1.75$ & $13.03^{\mathrm{b}} \pm 0.78$ & $22.3 \pm 1.62$ & $2.7^{\mathrm{a}} \pm 0.07$ & $240.30^{\mathrm{a}} \pm 0.94$ \\
$10 \mathrm{PP}$ & $56.4^{\mathrm{ab}} \pm 3.08$ & $12.23^{\mathrm{b}} \pm 0.92$ & $22.4 \pm 2.13$ & $2.7^{\mathrm{ab}} \pm 0.02$ & $224.19^{\mathrm{b}} \pm 0.78$ \\
20PP & $57.6^{\mathrm{a}} \pm 3.26$ & $11.86^{\mathrm{b}} \pm 1.26$ & $21.0 \pm 1.25$ & $2.6^{\mathrm{b}} \pm 0.07$ & $217.94^{\mathrm{b}} \pm 0.44$ \\
\hline
\end{tabular}

C: Control, 10BC: 10\% Bread crumbs, 10PP: 10\% Potato puree, 20PP: 20\% Potato puree

${ }^{\mathrm{a}-\mathrm{d}}$ Different superscripts in the same column indicate significant differences $(p<0.05)$.

Table 3. Cooking characteristics, WHC and penetrometer values of meatballs

\begin{tabular}{|c|c|c|c|c|c|}
\hline Sample & Cooking yield (\%) & Moisture retention (\%) & Fat retention (\%) & $\overline{\text { WHC }}$ & Penetrometer $(1 / 10 \mathrm{~mm})$ \\
\hline $\mathrm{C}$ & $59.7^{\mathrm{d}} \pm 1.52$ & $34.1^{b} \pm 2.82$ & $67.4^{\mathrm{c}} \pm 0.89$ & $0.67^{b} \pm 1.62$ & $22.6^{\mathrm{c}} \pm 0.78$ \\
\hline $10 \mathrm{BC}$ & $77.2^{\mathrm{a}} \pm 2.17$ & $41.1^{\mathrm{a}} \pm 2.11$ & $87.9^{\mathrm{a}} \pm 2.13$ & $0.72^{\mathrm{a}} \pm 2.11$ & $19.9^{\mathrm{d}} \pm 0.79$ \\
\hline $10 \mathrm{PP}$ & $63.0^{c} \pm 3.83$ & $35.5^{\mathrm{b}} \pm 1.62$ & $73.3^{b} \pm 1.03$ & $0.67^{b} \pm 0.43$ & $23.9^{b} \pm 0.57$ \\
\hline $20 \mathrm{PP}$ & $71.5^{\mathrm{b}} \pm 2.50$ & $41.2^{\mathrm{a}} \pm 1.19$ & $89.2^{\mathrm{a}} \pm 2.42$ & $0.64^{\mathrm{c}} \pm 0.93$ & $27.0^{\mathrm{a}} \pm 0.83$ \\
\hline
\end{tabular}

C: Control, 10BC: 10\% Bread crumbs, 10PP: 10\% Potato puree, 20PP: 20\% Potato puree

${ }^{\mathrm{a}-\mathrm{d}}$ Different superscripts in the same column indicate significant differences $(p<0.05)$.

$10 \%$ BC. Increasing PP from $10 \%$ to $20 \%$ increased cooking yield of meatballs $(p<0.05)$. Moisture retention in meatballs after cooking varied between 34.1-41.2\% (Table $3)$ and significantly affected by the addition of extender $(p<0.05)$. Fat retention varied between 67.4 and $89.2 \%$ (Table 3 ) and was signicantly affected by the addition of extender $(p<0.05)$.

The highest fat retention was obtained in samples extended with $20 \%$ potato puree. Samples extended with $\mathrm{BC}$ had similar fat retention as $20 \%$ PP added meatballs.

As seen in Table 3, WHC ranged between 0.64-0.72. Meatballs extended with $20 \%$ potato puree had higher WHC than other treatment groups. As seen in Table 3 penetretion values changed 19.9 to $27.0(1 / 10 \mathrm{~mm})$ Meatballs with $10 \% \mathrm{BC}$ had the lowest (the hardness in the texture) penetration values and meatballs with the $20 \%$ PP had the highest (the softness in the texture) penetration values.

Data for color parameters of the meatballs are presented in Table 4 . Adding extender significantly affected $\mathrm{L}^{*}$ values of meatball samples $(p<0.05)$. During storage significant differences were found on $\mathrm{L}^{*}$ values of $\mathrm{C}$ and 10PP samples $(p<0.05)$. At each evaluation period control samples had lower $L^{*}$ values than other treatment groups. Adding potato puree increased the $\mathrm{L}^{*}$ values of samples. On $0 \mathrm{~d}$ and at the end of the storage period control samples were darker than other treatment groups (lower $\mathrm{L}^{*}$ values), no significant differences were recorded in $L^{*}$ values of other treatment groups. $L^{*}$ values ranged between 32.8-37.3 at the end of the storage period.

On the $0^{\text {th }} \mathrm{d}$ meatballs without extender (control) had a* values that were slightly higher than $10 \mathrm{BC}, 10 \mathrm{PP}$ and 20PP samples Storage period had no effect $(p<0.05)$ on $a^{*}$ values of meatball samples. Meatball samples had a* values between 14.4-16.7 at the end of the storage. Storage period had no effect on $b^{*}$ values of meatball samples $(p<0.05)$.

TBA values of meatballs during storage at $4^{\circ} \mathrm{C}$ for $6 \mathrm{~d}$ are seen in Table 5. Storage period and extenders significantly affected the TBA values of meatball samples $(p<$ $0.05)$. On $0^{\text {th }}$ day control samples had the lowest TBA values $(0.42 \mathrm{mg} \mathrm{ma} / \mathrm{kg})$, TBA values for other treatment groups recorded $0.52,0.57$ and $0.48 \mathrm{mg} \mathrm{ma} / \mathrm{kg}$ for $10 \mathrm{BC}$, $10 \mathrm{PP}$ and 20PP respectively. During the storage period TBA values of all meatball samples increased, at the end of the storage period control samples had the highest TBA value $(0.98 \mathrm{mg} \mathrm{ma} / \mathrm{kg})$ whereas $10 \mathrm{BC}, 10 \mathrm{PP}$ and 20 PP samples had TBA values of $0.63,0.80,0.76 \mathrm{mg} \mathrm{ma} / \mathrm{kg}$ respectively.

Sensory properties for meatballs with different extenders are shown in Table 6. Meatballs added with potato puree had higher juiciness and flavor scores than other samples. No significant differences were obtained in appearance scores of meatball samples $(p<0.05)$. Data show that meatballs with formulated with 10 or $20 \%$ potato puree had significantly lower texture scores than $\mathrm{C}$ and 10BC 
Table 4. Colour values of uncooked meatballs during the storage at $2^{\circ} \mathrm{C}$ for $6 \mathrm{~d}$

\begin{tabular}{|c|c|c|c|c|}
\hline & \multicolumn{4}{|c|}{ Storage period (Day) } \\
\hline & 0 & 2 & 4 & 6 \\
\hline Sample & & & & \\
\hline $\mathrm{C}$ & $32.6^{\mathrm{bx}} \pm 1.34$ & $33.7^{\mathrm{bx}} \pm 1.81$ & $29.9^{\mathrm{cy}} \pm 1.72$ & $32.8^{\mathrm{bx}} \pm 0.44$ \\
\hline $10 \mathrm{BC}$ & $37.3^{\mathrm{a}} \pm 1.76$ & $36.7^{\mathrm{a}} \pm 1.05$ & $36.0^{\mathrm{b}} \pm 1.74$ & $36.6^{\mathrm{a}} \pm 1.00$ \\
\hline $10 \mathrm{PP}$ & $37.2^{\mathrm{ax}_{ \pm}} \pm 0.88$ & $34.6^{\mathrm{aby}} \pm 1.83$ & $36.5^{\mathrm{bxy}} \pm 0.96$ & $36.3^{\mathrm{axy}} \pm 1.89$ \\
\hline $20 \mathrm{PP}$ & $38.6^{\mathrm{a}} \pm 0.94$ & $36.6^{\mathrm{a}} \pm 2.17$ & $38.0^{\mathrm{a}} \pm 0.92$ & $37.3^{\mathrm{a}} \pm 2.10$ \\
\hline Sample & & & & \\
\hline $\mathrm{C}$ & $17.0^{\mathrm{a}} \pm 1.79$ & $15.1 \pm 3.61$ & $15.9 \pm 2.45$ & $15.4 \pm 4.48$ \\
\hline $10 \mathrm{BC}$ & $14.9^{\mathrm{b}} \pm 3.02$ & $14.8 \pm 2.94$ & $14.7 \pm 2.46$ & $15.2 \pm 2.92$ \\
\hline $10 \mathrm{PP}$ & $13.9^{\mathrm{b}} \pm 1.96$ & $15.5 \pm 2.47$ & $13.0 \pm 1.56$ & $14.4 \pm 3.51$ \\
\hline 20PP & $14.1^{\mathrm{b}} \pm 1.86$ & $16.1 \pm 3.37$ & $14.2 \pm 2.78$ & $16.7 \pm 0.91$ \\
\hline Sample & & & & \\
\hline $\mathrm{C}$ & $16.6^{\mathrm{ab}} \pm 0.76$ & $15.0^{\mathrm{b}} \pm 1.77$ & $15.1^{\mathrm{b}} \pm 0.95$ & $15.5^{\mathrm{b}} \pm 1.65$ \\
\hline $10 \mathrm{BC}$ & $17.8^{\mathrm{a}} \pm 0.77$ & $17.6^{\mathrm{a}} \pm 0.84$ & $17.8^{\mathrm{a}} \pm 0.29$ & $18.7^{\mathrm{a}} \pm 1.26$ \\
\hline $10 \mathrm{PP}$ & $16.2^{\mathrm{b}} \pm 0.82$ & $15.6^{\mathrm{ab}} \pm 1.49$ & $16.0^{\mathrm{ab}} \pm 1.39$ & $15.8^{\mathrm{b}} \pm 1.16$ \\
\hline $20 \mathrm{PP}$ & $17.3^{\mathrm{ab}} \pm 0.58$ & $17.1^{\mathrm{a}} \pm 0.86$ & $17.8^{\mathrm{a}} \pm 1.82$ & $18.0^{\mathrm{a}} \pm 0.83$ \\
\hline
\end{tabular}

C: Control, 10BC: 10\% Bread crumbs, 10PP: 10\% Potato puree, 20PP: 20\% Potato puree

${ }^{\mathrm{a}-\mathrm{c}}$ Treatments within the same storage condition with the same superscripts are not different.

${ }^{x, y}$ Storage conditions within the same treatment with the same superscripts are not different.

Table 5. TBA values values of uncooked meatballs during the storage at $2^{\circ} \mathrm{C}$ for $6 \mathrm{~d}(\mathrm{mg} \mathrm{ma} / \mathrm{kg})$

\begin{tabular}{cccc}
\hline \hline Sample & $0^{\text {th }}$ & $2^{\text {nd }}$ & $6^{\text {th }}$ \\
\hline C & $0.42^{\mathrm{bz}_{2}} \pm 0.09$ & $0.62^{\mathrm{by}} \pm 0.11$ & $0.98^{\mathrm{ax}} \pm 0.14$ \\
$10 \mathrm{BC}$ & $0.52^{\mathrm{ab}} \pm 0.10$ & $0.59^{\mathrm{b}} \pm 0.15$ & $0.63^{\mathrm{b}} \pm 0.19$ \\
$10 \mathrm{PP}$ & $0.57^{\mathrm{az}} \pm 0.05$ & $0.66^{\mathrm{aby}} \pm 0.15$ & $0.80^{\mathrm{abx}} \pm 0.02$ \\
$20 \mathrm{PP}$ & $0.48^{\mathrm{aby}} \pm 0.05$ & $0.68^{\mathrm{ax}} \pm 0.08$ & $0.76^{\mathrm{abx}} \pm 0.08$ \\
\hline
\end{tabular}

C: Control, 10BC: 10\% Bread crumbs, 10PP: 10\% Potato puree, 20PP: $20 \%$ Potato puree

${ }^{\mathrm{a}, \mathrm{b}}$ Treatments within the same storage condition with the same superscripts are not different.

${ }^{\mathrm{x}-\mathrm{z}}$ Storage conditions within the same treatment with the same superscripts are not different.

samples. The highest scores of overall acceptability were 5.4 and 5.3 respectively, for the 10PP and 10BC samples.

\section{Discussion}

The protein and fat contents of all meatballs were within the limits of Turkish Uncooked Meatball Standard (TSE, 2007) which are limited for protein content $12 \%$ minimum and for fat content $25 \%$ maximum. Adding extend- ers resulted decreament in fat content, the lowest fat content $(9.5 \%)$ was recorded for meatballs extended with $20 \%$ potato puree. Similar results were reported (Hsu and Yu, 1999; Ulu, 2006; Yilmaz and Daglioglu, 2003). Percentage fat and protein content increased and moisture content decreased on cooking for all treatment groups ( $p<$ 0.05). Replacement of meat with different levels of PP significantly reduced energy value of uncooked and cooked beef meatbllas. Mansour and Khalil (1997) obtained 41 and 33\% reductions in energy value of uncooked and cooked beefburgers, respectively, with added wheat fibre.

Cooking characteristics such as cooking yield, moisture and fat retention are the most important factors for the meat industry in predicting the behavior of products during cooking due to non-meat ingredients or other factors (Pietrasik and Li-Chan, 2002). Cooking loss occurs during the cooking process because of the moisture and fat loss. Meatballs formulated with $\mathrm{BC}$ and PP had higher cooking yields than control samples $(p<0.05)$. This improvement could be due to the increased in moisture binding by the added potato puree with skin on. Swelling

Table 6. Sensory properties of meatballs

\begin{tabular}{cccccc}
\hline \hline Sample & Appearance & Texture & Juiciness & Flavor & Overall Acceptability \\
\hline C & $5.5^{\mathrm{a}} \pm 0.85$ & $6.4^{\mathrm{a}} \pm 0.23$ & $3.6^{\mathrm{b}} \pm 0.64$ & $4.2^{\mathrm{b}} \pm 0.31$ & $3.66^{\mathrm{b}} \pm 0.23$ \\
$10 \mathrm{BC}$ & $4.7^{\mathrm{ab}} \pm 0.78$ & $4.8^{\mathrm{b}} \pm 0.42$ & $4.9^{\mathrm{a}} \pm 0.52$ & $4.9^{\mathrm{b}} \pm 0.52$ & $5.3^{\mathrm{a}} \pm 0.20$ \\
$10 \mathrm{PP}$ & $4.8^{\mathrm{ab}} \pm 0.57$ & $2.2^{\mathrm{c}} \pm 0.23$ & $4.9^{\mathrm{a}} \pm 0.54$ & $6.0^{\mathrm{a}} \pm 0.93$ & $5.4^{\mathrm{a}} \pm 0.95$ \\
$20 \mathrm{PP}$ & $4.4^{\mathrm{b}_{\mathrm{b}}} \pm 0.63$ & $2.0^{\mathrm{c}} \pm 0.20$ & $4.0^{\mathrm{b}} \pm 0.34$ & $6.4^{\mathrm{a}} \pm 0.84$ & $4.0^{\mathrm{b}} \pm 0.49$ \\
\hline
\end{tabular}

C: Control, 10BC: 10\% Bread crumbs, 10PP: 10\% Potato puree, 20PP: $20 \%$ Potato puree

${ }^{\mathrm{a}-\mathrm{c}}$ Different superscripts in the same column indicate significant differences $(p<0.05)$. 
Table 7. Correlation coefficients between sensory texture value and penetration value of samples

\begin{tabular}{ccccc}
\hline \hline \multirow{2}{*}{$\begin{array}{c}\text { Sensory texture } \\
\text { scores }\end{array}$} & \multicolumn{4}{c}{ Penetration value } \\
\cline { 2 - 5 } & $\mathrm{C}$ & $10 \mathrm{BC}$ & $10 \mathrm{PP}$ & $20 \mathrm{PP}$ \\
\hline $\mathrm{C}$ & 0.876 & & & \\
$10 \mathrm{BC}$ & & -0.263 & & \\
$10 \mathrm{PP}$ & & & -0.060 & \\
$20 \mathrm{PP}$ & & & & 0.981 \\
\hline
\end{tabular}

C: Control, 10BC: 10\% Bread crumbs, 10PP: 10\% Potato puree, 20PP: $20 \%$ Potato puree

properties of dietary fiber and starch in potatoes increased cooking yield of meatball samples. These results agree with those of Wang and Xiong (2005), who showed that the addition of hydrolyzed potato protein reduced the cooking losses of patties. Ali et al. (2011) reported that increasing potato flake in beef patty formulation increased cooking yield. The cooking yield was found $98.97 \%$ in meatballs formulated with potato flour (Ikhlas et al., 2011). Ulu (2004) reported cooking yield of $41.3-49.32 \%$ for meatballs extended with wheat flour. Moisture retention in ground meat products is an important cooking parameter, since retained moisture in the product affects eating quality. Control samples lost more moisture during cooking than the extender added samples $(p<0.05)$. 10BC samples showed similar moisture retention values with 20PP samples. Serdaroglu and Degirrmencioglu (2004) reported $36.53-44.70 \%$ moisture retention in meatballs added with $0,2,4 \%$ corn flour and formulated with 5,10, $20 \%$ fat. Prinyawiwatkul et al. (1997) observed that chicken nuggets extended with $10 \%$ cowpea our had higher moisture retention values. Addition different levels of starch led to increase the retention of moisture in beef patties (El-Beltagy et al., 2007; Mansour and Khalil, 1997). Control samples had the lowest fat retention $(p<0.05)$. In these samples with no added extender fat was more easily removed during cooking, probably due a low density meat protein matrix, along with a high fat instability. This is in agreement with previous research studies (Pinero et al., 2008; Suman and Sharma, 2003). The highest fat retention was obtained in samples extended with $20 \%$ potato puree $(p<0.05)$. The swelling of the starch and bre, in addition to some fat absorption by the bre, may interact with the protein of the ground meat matrix thereby acting to prevent migration of fat from the product (Anderson and Berry, 2001). Ground beef appears to be uniquely suited for investigations on enhancing fat retention because its physical state makes it more susceptible to fat losses during cooking. Product formulation and processing methodology are key determinants of fat loss and weight loss during the cooking of products such as sausages and burgers (Sheard et al., 1989). There was a possible connection between increasing cooking yield and higher fat retention. Similar results were reported by Serdaroglu and Degirmencioglu (2004), who also found that higher cooking yield was accompanied by higher fat retention. Retaining fat within the matrix of meat products during processing is necessary to ensure sensory quality and acceptability. However Anderson and Berry (2001) indicated that increased cooking yield does not always result in higher fat retention. Water holding capacity is an important function of proteins in processed meat products. Meatballs extended with $20 \%$ potato puree had higher WHC than other treatment groups. The ability of potato puree to hold water in meatballs has favorable implications in the final product quality by preventing excessive moisture loss in meatballs. This increase in water holding capacity may be due to the ability of starch in PP to absorb and keep more of water. As a result a much more stable meat protein matrix is formed which leads to a smaller release of water and fat thus improving binding properties of restructured meats (Carballo et al., 1995; Pietrasik and Shand, 2003). Ali et al. (2011) reported similar results in low fat beef patties extended with potato flake.

Factors responsible for textural properties in comminuted meat proteins are degree of extraction of myobrillar proteins, stromal protein content, degree of comminuting and type and level of non-meat additives. The swelling of the starch and dietary fiber component of potato puree may interact with the protein of meat to form a softer texture thus leading to an increase in penetrometer values. However in our pervious research meatballs extended with $10 \%$ rusk had higher penetration values than meatballs extended with $10 \%$ black eye bean flour, lentil flour and chickpea flour (Serdaroglu et al., 2005). Binders or extenders may be used without added water or with added water, which was reported to cause a softening effect on the texture (Kurt and Kilincceker, 2012). Adding extender significantly increased $\mathrm{L}^{*}$ values of meatball samples $(p<0.05)$. The lighter color was observed for meatballs formulated with $\mathrm{PP}$ and $\mathrm{BC}$ compared to control which could be attributed to the dilution of the meat pigment and in turn, increase the $L^{*}$ values. Serdaroglu (2006) reported that adding oat flour to beef patties at a level of 2 or $4 \%$ resulted in increased lightness. Previous results were similar to our results, Elgasim and Al-Wesali (2000) observed that all beef control patties had higher a* values than samples containing soy protein and samh flour. These 
results would be expected based on earlier observations by the researchers of the myoglobin diluting effect of potato puree. Similarly Ulu (2004) reported that incorporation of wheat flour, soy protein and whey protein had no detrimental effect on colour. Control samples had slightly lower $\mathrm{b}^{*}$ values than $\mathrm{BC}$ and $\mathrm{PP}$ added samples at each evaluation period. This might be a result of the presence of carotenoid pigments BC and PP. Similar to our results Yilmaz and Daglioglu (2003), observed that all beef control meatballs had lower $b^{*}$ values than meatballs containing oat bran.

Potato puree showed antioxidative effect during storage period of meatballs. It is possible that the antioxidative phenolic compounds that are normally present in potato skin could have contributed to the stronger antioxidative activity. It was reported by Lisinska and Leszczynski (1987) that potato peel contains phenolic acids, the largest portion of which consists of chlorogenic acid (50.31\%). Other phenolic compounds such as gallic acid (41.67\%), protocatechuic $(7.81 \%)$ and caffeic acids $(0.21 \%)$ were also present in potato peel Sotillo et al. (1994). Mansour and Khalil (2000) showed the antioxidant activity of freeze dried extracts from potato peel in ground beef patties. Nieto et al. (2009) reported that hydrolyzed potato protein showed inhibitory effect on lipid oxidation on cooked frankfurters during the storage. However in our research $\mathrm{BC}$ at a level of $10 \%$ found as effective as PP on preventing lipid oxidation during the storage. Ascorbic acid content of BC presumably retarded oxidative changes and resulted lower TBA values. Similarly in our previous research we also found the antioxidative effect of rusk (Serdaroglu et al., 2005). Ulu (2004) also reported the antioxidative effect of wheat flour on meatballs. All meatball samples had TBA values within consumable limits (Schormuller, 1969).

Sensory properties are among the major concerns for the utilization of plant proteins in foods. Potato pruree addition increased juiciness and favour csores of meatballs. Likewise in a study performed by Candogan (2002) tomato puree addition at concentrations of $10 \%$ increased juiciness of patties. The results of Ali et al. (2011) indicated that extending low fat beef patties with potato flake had no effect on flavor scores of beef patties. Lower texture scores attributed to extensively softening in meatball texture. Sensory texture scores had high correlations with penetration values (Table 7). Similar to our research Hsu and Chung (1998) and Ikhlas et al. (2011) indicated a positive correlation between hardness and overall acceptance, which means that consumers generally prefer harder textures. However, these higher values for texture (hardness) do not necessarily mean better quality. $10 \%$ potato puree was received with overall acceptability. This acceptance was due to the suitability of potato puree at a level of $10 \%$ in flavour and texture.

In conclusion the addition of potato puree reduced energy values of meatballs and improved cooking properties. PP addition and BC addition inhibited lipid oxidation during cold storage. Meatballs extended with PP and BC had similar sensory scores except texture. PP resulted softening in texture of meatballs. Further research should be done on improving texture of meatballs added with potato puree.

\section{References}

1. Ali, R. F. M., El-Anany, A. M., and Gaafar, A. M. (2011) Effect of potato flakes as fat replacer on the quality attributes of low-fat beef patties. Adv. J. Food. Sci. Tech. 3, 173-180.

2. Anderson, E. T. and Berry, B. W. (2001) Effects of inner pea fiber on fat retention and cooking yield in high fat ground beef. Food Res. In. 34, 689-694.

3. AOAC (2007) Official methods of analysis. 18th ed, Association of Official Analytical Chemists, Washington, DC, p. 931.

4. Bengtsson, H., Montelius, C., and Tornberg, E. (2011) Heattreated and homogenised potato pulp suspensions as additives in low-fat sausages. Meat Sci. 88, 75-81.

5. Candogan, K. (2002) The effect of tomato paste on some quality characteristics of beef patties during refrigerated storage. European Food Res. Tech. 215, 305-309.

6. Candogan, K. and Kolsarici, N. (2003) Storage stability of low-fat beef frankfurters formulated with carrageenan or carrageenan with pectin. Meat Sci. 64, 207-214.

7. Carballo, J., Mota, N., Barreto, G., and Jimenez-Colmenero, F. (1995) Binding properties and colour of Bologna sausages made with varying fat levels protein levels and cooking temperatures. Meat Sci. 41, 301-313.

8. Colmenero, F. J., Ayo M. J., and Carballo, J. (2005) Physicochemical properties of low sodium frankfurter with added walnut: effect of transglutaminase combined with caseinate, $\mathrm{KCl}$ and dietary fibre as salt replacers. Meat Sci. 69, 781-788.

9. Deda, M. S., Bloukas, J. G., and Fista G. J. (2007) Effect of tomato paste and nitrite level on processing and quality characteristics of frankfurters. Meat Sci. 76, 501-508.

10. Devatkal, S., Mendiratta, S. K., and Kondaiah N. (2004) Quality characteristics of loaves from buffalo meat, liver and vegetables. Meat Sci. 67, 377-383.

11. El-Anany, A. M. and Ali, R. F. M. (2007) Effect of mixing rusk with various levels of potato peel powder during frying and storage processes. Electron. J. Environ. Agric. Food Chem. 6, 1828-1837.

12. El-Beltagy, A. E., Boudy, E. A., and Gaafar, A. M. (2007) Quality characteristics of low- fat beef patties formulated With 
Jerusalem artichoke (Helianthus tuberosus L.). J. Agric. Env. Sci. 6, 1-15.

13. El-Magoli, S. B., Laroia, S., and Hansen, P. T. M. (1996) Flavour and texture characteristics of low fat ground beef patties formulated with whey protein concentrate. Meat Sci. 42, 179193.

14. Elgasim, E. A. and Al-Wesali, M. S. (2000) Water activity and hunter colour values of beef patties extended with samh (Mesembryanthemum forsskalei Hochst) flour. Food Chem. 69, 181-185.

15. Ergezer, H. and Serdaroglu, M. (2009) The effect of broccoli puree on some quality characteristics of beef meatballs. 55th International Congress of Meat Science and Technology, August 16-21, Copenhagen, Denmark.

16. Fista, G. A., Bloukas, J. G., and Siomos, A. S. (2004) Effect of leek and onion on processing and quality characteristics of Greek traditional sausages. Meat Sci. 68, 163-172.

17. Flynn, A. W. and Bramblett, V. D. (1975) Effects of frozen storage cooking method and muscle quality and attributes of pork loins. J. Food Sci. 40, 631-633.

18. Garcìa, M. L., Calvo, M. M., and Selgas, M. D. (2009) Beef hamburgers enriched in lycopene using dry tomato peel as an ingredient. Meat Sci. 83, 45-49.

19. Gujral, H. S., Kaur, A., Singh, N., and Sodhi, N. S. (2002) Effect of liquid whole egg, fat and textured soya protein on the textural and cooking properties of raw and baked patties from goat meat. J. Food Eng. 53, 377-385.

20. Hedrick, H. B., Aberle, E. D., Forrest, J. C., Judge, M. D., and Merkel, R. A. (1994) Nutritive value of meat. Principles of meat science. 3rd ed. 289-298 Kendall Hunt Publishing, Dubuque Iowa.

21. Hsu, S. Y. and Chung, H. Y. (1998) Effect of processing factors on qualities of emulsified meatball. J. Food Eng. 36, 337347.

22. Hsu, S. Y. and Yu, S. H. (1999) Effects of phosphate, water, fat and salt on qualities of low-fat emulsified meatball. $J$. Food Eng. 39, 123-130.

23. Ikhlas, B. and Huda-Noryati, N. (2011) I. Chemical composition and physicochemical properties of meatballs preparedfrom mechanically deboned quail meat using various types of flour. Int. J. Poultry Sci. 10, 30-37.

24. Kurt, S. and Kilincceker, O. (2012) The effects of cereal and legume flours on the quality characteristics of beef patties. Kafkas Univ. Vet. Fak. Derg. 18, 725-730.

25. Lisinska, G. and Leszczynski, W. (1987) Potato tubers as raw material for processing and nutrition. G. Lisinska, and W. Leszczynski (ed.): Potato Science and Technology. 34-38, Elsevier Applied Science, London, England.

26. Mansour, E. H. and Khalil, A. H. (1997) Characteristics of low-fat beef burgers as influenced by various types of wheat fibres. J. Food Sci. Agric. 79, 493-498.

27. Mansour, E. H. and Khalil, A. H. (2000) Evaluation of antioxidant activity of some plant extracts and their application to ground beef patties. Food Chem. 69, 135-141.

28. Murphy, E. W., Criner, P. E., and Grey, B. C. (1975) Comparison of methods for calculating retentions of nutrients in coo- ked foods. J. Agric. Food Chem. 23, 1153-1157.

29. Nieto, G., Castillo, M., Xiong, Y. L., Alvarez, D., Payne, F. A., and Garrido, M. D. (2009) Antioxidant and emulsifying properties of alcalase-hydrolyzed potato proteins in meat emulsions with different fat concentrations. Meat Sci. 83, 24-30.

30. Nunez de Gonzalez, M. T., Boleman, R. M., Miller, R. K., Keeton, J. T., and Rhee, K. S. (2008) Antioxidant properties of dried plum ingredients in raw and precooked pork sausage. J. Food Sci. 73, 63-71.

31. Pietrasik, Z. and Li-Chan, E. C. Y. (2002) Response surface methodology study of the effect of salt, microbial transglutaminase and heating temperature on pork batter gel properties. Food Res. Int. 35, 387-396.

32. Pietrasik, Z. and Shand, P. J. (2003) The effect of quality and timing of brine addition on binding and textural characteristic of cooked beef rolls. Meat Sci. 65, 771-778.

33. Pinero, M. P., Para, K., Huerta-Leidenz, N., de Moreno, L., Ferrer, A., M., and Araujo, S. (2008) Effect of oat's soluble fibre (beta-glucan) as a fat replacer on physical, chemical, microbiological and sensory properties of low-fat beef patties. Meat Sci. 80, 675-680.

34. Pizzocaro, F., Senesi, E., Veronese, P., and Gasparolo, A. (1998) Mechanically deboned poultry meat hamburgers. II. Protective and antioxidant effect of carrot and spinach tissues during frozen storage. Industrie Alimentari. 37, 710-720.

35. Prinyawiwatkul, W., McWatters, K. H., Beuchat, L. R., and Phillips, R. D. (1997) Physicochemical and sensory properties of chicken nuggets extended with cowpea and peanut flours. J. Agric. Food Chem. 45, 1891-1899.

36. Puolanne, E. and Ruusunen, M. (1983) Einfluss des Salzzusatzes auf das Wasserbindungsvermögen des Fleisches in Brühwurst verschiedener Rezepturen. Fleischwirtschaft 63, 238-239. (DE)

37. Purma, C. and Serdaroglu, M. (2008) Effects of dried apricot pulp on functional properties of beef sausages. 52nd International Congress of Meat Science and Technology, August 1318, Dublin, Ireland.

38. Schormuller, J. (1969) Handbuch der Lebensmittel Chemie Bond IV Fette und Lipids. Springer-Verlag, Berlin. (DE)

39. Serdaroglu, M. (2006) Improving low fat meatball characteristics by adding whey powder. Meat Sci. 72, 155-163.

40. Serdaroglu, M. and Degirmencioglu, O. (2004) Effects of fat level $(5,10,20 \%)$ and corn flour $(0,2,4 \%)$ on some properties of Turkish type meatballs (Koefte). Meat Sci. 68, 291-296.

41. Serdaroglu, M., Yildiz-Turp, G., and Kiyalbek, A. (2005) Quality of low-fat meatballs containing Legume flours as extenders. Meat Sci. 70, 99-105.

42. Sheard, P. R., Nute, G. R., and Chappell, A. G. (1998) The effect of cooking on the chemical composition of meat products with special reference to fat loss. Meat Sci. 49, 175-191.

43. Sotillo, D. R., Hadley, M., and Holm, E. T. (1994) Potato peel waste: Stability and antioxidant activity of a freeze-dried extract. J. Food Sci. 59, 1031-1033.

44. SPSS (2003) SPSS Statistical package for windows, ver. 13.0, Chicago, IL: SPSS Inc.

45. Suman, S. and Sharma, B. (2003) Effect of grind size and 
levels on the physico-chemical and sensory characteristics of low-fat ground buffalo meat patties. Meat Sci. 65, 973-976.

46. Tarladgis, B. G., Watts, B. M., and Yonathan, M. (1960) Distillation method for the determination of malonaldehyde in rancid foods. J.A.O.C.S. 37, 44-48.

47. TSE (2007) Pipmemip Köfte Standardý (Turkish Uncooked Meatball Standard, TS 10581:T5) Ankara Türk Standartlarý Enstitüsü. (TR)

48. Turhan, S., Sagir, I., and Sule Ustun, N. (2005) Utilization of hazelnut pellicle in low-fat beef burgers. Meat Sci. 71, 312316.

49. Ulu, H. (2004) Effect of wheat flour, whey protein concentrate and soya protein on oxidative processes and textural properties of cooked meatballs. Food Chem. 87, 523-529.

50. Ulu, H. (2006) Effects of carrageenan and guar gum on the cooking and textual properties of low fat meatballs. Food Chem. 95, 600-605.
51. Wang, L. L. and Xiong, Y. L. (2005) Inhibition of lipid oxidation in cooked beef patties by hydrolyzed potato protein is related to its reducing and radical scavenging ability. J Agric Food Chem. 53, 9186-9192.

52. Xu, Y. (2001) Perspectives on the 21 st century development of functional foods: Bridging Chinese medicated diet and functional foods. Int. Food Sci. Tech. 36, 229-242.

53. Yildiz-Turp, G. and Serdaroglu, M. (2010) Effects of using plum puree on some properties of low fat beef patties. Meat Sci. 86, 896-900.

54. Yilmaz, I. and Daglioglu, O. (2003) The effect of replacing fat with oat bran on fatty acid composition and physicochemical properties of meatballs. Meat Sci. 65, 819-823.

55. Zayas, F. J. and Lin, C. S. (1998) Quality characteristics of frankfurters containing corn germ protein. J. Food Sci. 53, 1587-1591.

(Received 2013.12.24/Revised 2014.2.11/Accepted 2014.9.26) 